\title{
Mixing methods, tasting fingers Notes on an ethnographic experiment
}

\author{
Anna Mann, University of Amsterdam, Annemarie \\ MOL, University of Amsterdam, Priya SATALKAR, \\ Amalinda SAVIRANI, Gadjah Mada University, \\ Nasima SELIM, BRAC University, Malini SUR, \\ University of Amsterdam, Emily YATES-DOERR, \\ University of Amsterdam
}

This article reports on an ethnographic experiment. Four finger eating experts and three novices sat down for a hot meal and ate with their hands. Drawing on the technique of playing with the familiar and the strange, our aim was not to explain our responses, but to articulate them. As we seek words to do so, we are compelled to stretch the verb "to taste." Tasting, or so our ethnographic experiment suggests, need not be understood as an activity confined to the tongue. Instead, if given a chance, it may viscously spread out to the fingers and come to include appreciative reactions otherwise hard to name. Pleasure and embarrassment, food-like vitality, erotic titillation, the satisfaction or discomfort that follow a meal-we suggest that these may all be included in "tasting." Thus teasing the language alters what speakers and eaters may sense and say. It complements the repertoires available for articulation. But is it okay? Will we be allowed to mess with textbook biology in this way and interfere, not just with anthropological theory, but with the English language itself?

Keywords: method, tasting, food, experiment, fingers, fluid, senses

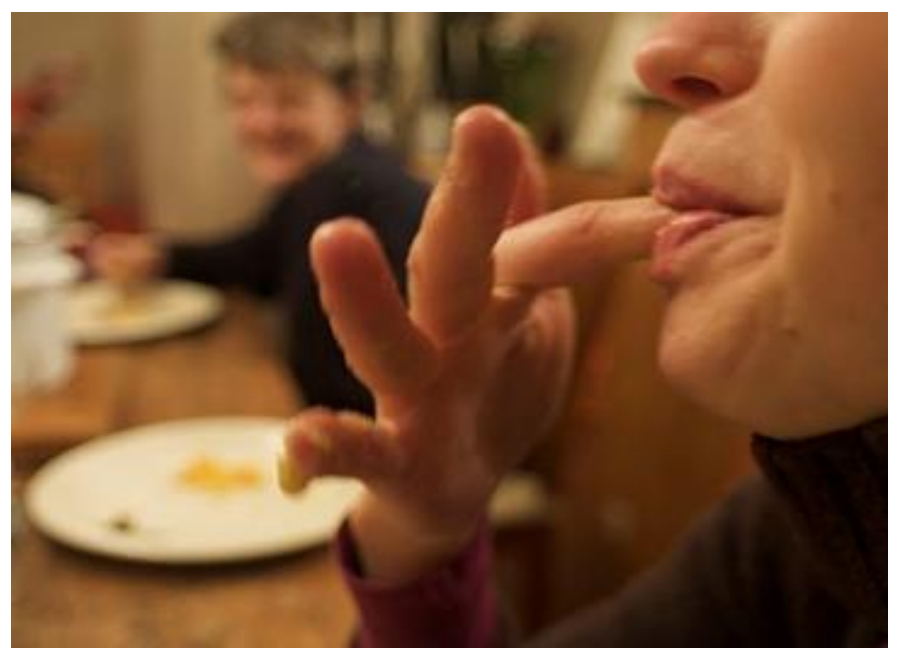

This work is licensed under the Creative Commons | (c) Anna Mann. Attribution-NonCommercial-NoDerivs 3.0 Unported. ISSN 2049-1115 (Online) 
It all began with a comment from Malini. She said that when you eat with your fingers the food tastes better. This has not just to do with the absence of utensils. There is more. When you eat with your fingers, tasting doesn't start once the food reaches the tongue. There is already tasting in the fingers.

Anna studies what it is to taste. 'Thus, after Malini's remark she went to look up manual eating in the literature. What she found went in many directions. In the nursing literature, manual eating is discussed as a possible solution for people with dementia who have trouble coordinating their movements (Perrin, May, and Anderson 2008). Historically oriented sociological studies explore how utensils were first used in French courts and from there gradually "moved down" to aspiring bourgeois and finally even to peasants. Their use came to index what the West celebrated-and still celebrates-as its own "civilizing process." Fork and spoon created a distance between eating body and foods to be eaten that helped to differentiate rational man from animals and savages (Elias [1939] 1997). Chopsticks, in their own context, and for similar reasons, are signs of civilization as well. They help in avoiding dirty hands, and allow knives (that may double as weapons) to be banned from the dinner table. And then there is academic attention given to pollution taboos that accompany manual eating. In most places where people eat with their hands it is not eating that is classified as dirty, but rather other activities that hands may engage in, notably bottom-wiping. This leads to a division of labor between the left hand, used for bottom-wiping and forbidden to touch food, and the right hand, used for eating and forbidden to touch feces (Douglas 1966).

These varied literatures on eating practices have little or nothing to say about tasting. The anthropology of the senses, in its turn, doesn't mention hands. It locates taste on the tongue. It is infused with the hope that studying taste (along with smell) will "liberate us from the hegemony which sight has for so long exercised over our own culture's social, intellectual, and aesthetic life" (Howes 1991: 4). (Note that in this literature "our own" culture is supposed to be Western). Inquiries address how tasting and smelling relate to other aspects of cultural life, how they evoke memories, help to frame collective identities and foster feelings of belonging (Sutton 2001; Stoller 1989; Seremetakis 1996; Law 2001). They also open up questions to do with the terms suitable for talking about taste. The tastes sciences have five taste-categories on offer: sweet, sour, bitter and salty (mentioned already in Aristotle) and umami (a term that was successfully introduced into the international arena by Japanese researchers; the typical reference dish is meatbroth). But outside of the scientific laboratory other taste terms circulate. A lot of them. For example, wine tasters use a wide gamut of words to describe the flavors of wine, from "full bodied" and "briary" to "herbaceous" and "weighty" (Teil 1997). The Ayurveda tradition has terms that translate into English as sweet, sour, bitter and salty, but it adds pungent and astringent (Freeman 2011). And in the language of Samburu pastoralists, the terms kemelok, kesukut and kesagamaka make it

1 We gratefully acknowledge the ERC support to three of the authors that forms a crucial condition of possibility for this article. Next, we would like to thank Sebastian Abrahamsson, Filippo Bertoni, Rebeca Ibanez Martin, Marianne de Laet and Cristobal Rodrigo Bonelli for discussion and inspiration. Thanks as well to John Law, Mattijs van de Port and Mieke Aerts for comments and encouragements. And finally we are greatly indebted to two anonymous HAU reviewers. 
possible to differentiate between good milk, milk that has gone slightly sour, and milk that is no longer drinkable (Holtzman 2009).

But while the anthropology of the senses brings to the fore that people may variously relate to a dazzling diversity of flavors, so far it holds on to the idea that human beings have "senses"-separate sense organs that are located in specific bodily sites. Eyes see; ears hear; the nose smells. Taste receptors are found on the tongue. Fingers, accordingly, do not taste. Instead, thanks to sensory receptors in the skin, fingers touch. ${ }^{2}$ This is basic textbook biology, so how might one begin to question it? Utensil-users may not realize there is room for doubt here. Fingereaters, in their turn, may not be eager to explore the sensuous ventures of their eating fingers. Why raise the suspicion of Westerners, just about prepared to take you seriously, that you lack "civilization" after all $?^{3}$ It seems more prudent to keep your food pleasures to yourself.

Malini, however, was prepared to share her pleasures. ${ }^{4}$ She offered to give Anna a lesson. In the corridors of the Institute additional investigators were easy to find. And thus it happened that on a cold Saturday evening in January 2011 four finger eating experts (brought up with the technique) and three novices (used to eating with utensils) came together in a small Amsterdam apartment with a large kitchen. The experts had each shopped for, and were to cook, a vegetarian dish suitable for the occasion. ${ }^{5}$ Serving spoons would be used to dish the food onto

2 Even Michel Serres (1995) reinforces with the very title of his rebellious book on practices of sensing that there are "five senses." Elsewhere, the universality of "the senses" is being challenged. See for instance Geurts (2002) who tells how the Anlo-Ewe in Ghana care for a sense of "balance" that allows one to carry heavy loads on one's head as well as to be a balanced person. In cultures drawing on Sanskrit, the five senses come back as Roop (Visual forms), Shabda (Sound), Gandha (Smell), Swad (Taste), Sparsha (Touch) but they are supplemented with Rasa, the ability to appreciate that pervades all the other senses (Higgins 2007). There is obviously a lot left to explore here.

3 A small but telling example can be found in public reactions to the Indian actress Shilpa Shetty's participation in the British version of Celebrity Big Brother in 2007. Racist tropes were freely ventured when it appeared that she ate her cooked meals with her fingers-which in later reports got "softened" into a "problem with her eating habits.” http://en.wikipedia.org/wiki/Shilpa_Shetty\#Celebrity_Big_Brother_racism_ controversy

4 It is only once an earlier version of this text was finished and submitted, that Anna found work attentively comparing finger eating and utensil eating. Art work. A film of two men sitting at opposite ends of a table, one eating with fork and knife, the other with his fingers. While they eat, they discuss the pros and cons of these two modes of eating that they both appear to be familiar with. Such as: "You see, the advantage of eating with fork and knife is that you don't risk the chance of burning your fingers." Pause, chewing. "The advantage of eating with your fingers is that you don't risk the chance of burning your mouth" (Subbaiah 1997).

5 At least: we cooked a meal that in our shared Amsterdam kitchen we called "vegetarian"-because there was no meat. Or should we say: because there was no meat and no fish and no poultry? In some places, after all, the latter two do not count as "meat." One of our reviewers tells us that our vegetarianism, too, is local, because onions and garlic are defined as "non-vegetarian" in e.g. South Asian Hindu or Jain food classification systems. See Fruzzetti and Ostor (1984). 
separate, individual plates, but smaller spoons, forks and knives would remain in their drawers. We would eat. There was a camera for shared use and afterwards we would all make field notes. If our materials and analysis would be rich enough, we hoped to write a joint article about them.

This, then, is that article. It reports on an event: a single evening and the experiment that we engaged in then and there. We will present two separate-if related-analyses of this event. One has to do with the tasting that we set out to study. The other has to do with method. For our (so called) method seemed at least as interesting as our (so called) findings. This is because our method is a mixture. It is a composite of divergent, clashing ways of working, irrevocably changed in the process of mixing them together. We were inspired by laboratory experiments, but did not comply with all of their rules. We did anthropological fieldwork, but not of the traditional kind. Both methods changed as we mixed the experimental organization of an event with the open attentiveness of fieldwork. And the mixing went on. We mixed being a researcher-subject with being an object of research. In terms that befit an experiment: each of us figured as both laboratory technician and guinea pig. In fieldwork terms: we were all ethnographers as well as informants. There were differences and similarities between the tasks that we engaged in. Only some of us selected the ingredients and directed the cooking, but we all chopped at least some vegetables. While we related to our food in different ways, we all ate and enjoyed it. We all talked (a lot), but had diverse things to say. We all made notes, but they went in different directions. Some of us spent more time with this text than others, but we all read through its various versions and suggested adaptations. In this way an author-composite, an intricate mixture of passions and skills, was essential to the writing of this article, so we all sign it, in alphabetical order of our family names. ${ }^{6}$

But what is it to do so? Does the mere resolve to write collectively provide "us" with a single voice? Of course not. The viscous composite that "we" form holds insolvable differences within it. Crucially, when it comes to eating with fingers (the focus of the experiment) some of us are experts, others novices. In the course of our lives we have eaten different foods in different ways. As academics we differ, too. We work on different topics and while "tasting" is a core topic for some, for others it is only of peripheral interest. Our writing experiences differ in yet other ways. Instead of a unity, then, "we" are an assemblage of partially connected figures. But an assemblage is not an addition. It does not so much resemble a wall built out of separate stones, as it does a dish cooked from varied ingredients. Once mixed together, the ingredients can no longer be separated out. To express this complex situation in "our" writing, this text will play with its author pronouns. There are sentences that hide their author (like the present sentence). Sometimes "we" will stage a collective author who says "we," even though "we" are not equally invested in "our" utterances. From time to time an "I" will separate itself off to speak for itself. Like this: I will express myself in italics. When relevant, the "I" will be

6 In slightly different circumstances, there may be good reasons for not signing joint work collectively. As authorship comes to be variously shared, experimenting with different modes and modalities of juxtaposing voices is in order. See about this issue also the Matsutake World Research Group, e.g Choy, Faier, Hathaway, Inoue, Satsuka and Tsing (2009). 
granted a name, but if the name just does not matter it is left out. Our "I" is not a liberal subject that preceded our dinner, it only emerged thanks to a singular and shared experiment and the process of writing that followed from it. Our "we," likewise, is not an addition of separate individuals, but an ephemeral amalgamate that materialized thanks to the occasion.

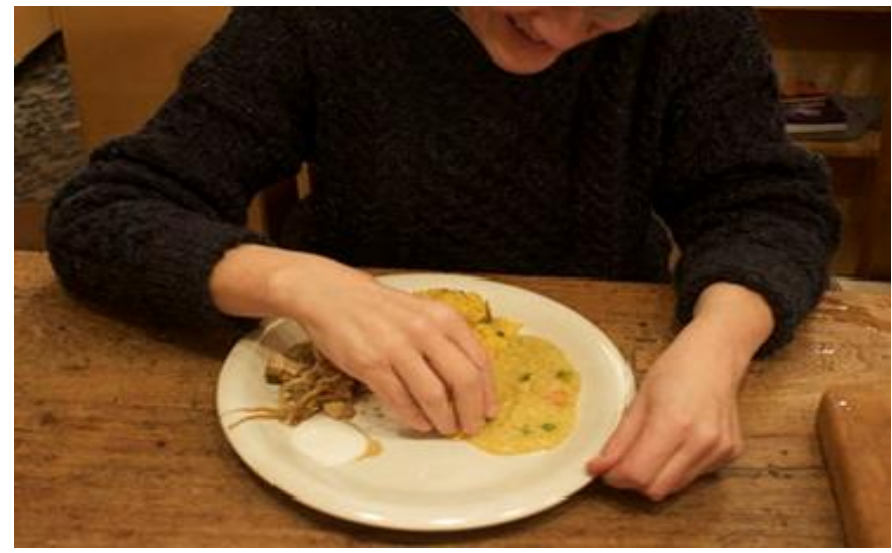

Beware: our experiment was not set up to study "the body" or "the sense of taste." Instead, we staged a singular event, a particular juxtaposition of questions, bodies, foods, work and pleasure. Thus, we do not promise you general knowledge about "tasting fingers," but instead propose a particular configuration of what "tasting fingers" may be. The meal we ate is particular, too: you would not find its messy collection of dishes elsewhere, but it served our experiment well. To underline the willful artificiality of the occasion, the pictures that we present you with do not show faces-at most fragments thereof. Our concern is rather with hands. With fingers. Fingers that mash foods on a plate and get sticky in the process-making it awkward to write notes. Fingers that (skillfully or clumsily) prepare a bite and carry it to the mouth. Fingers that engage with warmth, texture, shapes. Fingers that are being licked clean. How might they alter tasting?

Our point is not to reallocate the sense of taste away from the mouth to the fingers. Instead, it is to interfere with "tasting." We want to twist and turn, mash and mix, stretch and fold the use of that term. How to do so? Different languages offer different possibilities for topicalizing tasting. ${ }^{7}$ There is no neutral one and though the list of the languages at least one of us speaks is a long one, we share only English between us. Not coincidentally English is also the language of international academic life-and of this journal. It crucially informs what circulates as "theory." ${ }^{8}$ Here, we seek to interfere with the language of "theory" by drawing

7 In Bengali, for instance, appreciation would be discussed differently than in English, as the term rasa directly supplements perception with appreciation. But Dutch, too holds possibilities that English lacks, e.g. those afforded by the term lekker that may translate as tasty but also evokes other positive bodily sensations. This also begs the question in which ways appreciation of food and appreciation of sex are variously differentiated and connected. See for this for example Judith Farquhar's (2002) insightful study of food and sex in China.

8 Crucial inspiration for taking theory as culture is the work of Marilyn Strathern (e.g. 1992). 
on modest means: the ethnographic witnessing of a single experiment. To stay focused we will limit ourselves to what, stretching and betraying it, we are able to articulate in English, the language we spoke at our dinner table. What did we learn from our experiment that might alter this elusive English verb: to taste?

\section{Methods}

This is not a methods section meant to reassure you. We are not out to guarantee that our findings are trustworthy. Instead, we indicate where our research techniques come from, so as to elucidate where they might lead. For mind you, the work we engaged in does not fit the standard description of "mixed methods." We did not combine qualitative with quantitative work, if only because we counted nothing. Instead, we mixed together a version of the laboratory experiment with techniques pertaining to ethnographic fieldwork.

I was not supposed to be there. The experiment was meant to bring together six anthropologists: one MS student (earlier trained as a medical doctor), three PhD students, a postdoc and a full professor. But then Nasima had a visitor for the weekend. She knew Priya from a public health course in Dhaka. Could her guest join in? With a single email the matter was settled. Nasima introduced me to the others as one of her "key ingredients." She gave me a new identity. Who I am? I am a key ingredient of a Khichuri or Khichadi in my mother tongue. But I am not the key ingredient of any Khichadi. No, I am a key ingredient of this specific Khichadi that seven of us cooked together in one high-tech but still cozy and inviting kitchen inhabited by an American anthropologist who, for the time being, lives in Amsterdam. I feel this context matters as it is this context that makes all the difference, to the Khichadi, to the taste, to the aromas, to the fingers and of course to me. The contrast, here, is with laboratory experiments. Laboratory researchers stick to their plans. Seeking to be in control, they do not welcome in new research subjects along the way, nor do they allow themselves to be changed by their experiments. Only the variables under study are allowed to vary. In our experiment, by contrast, we fixed little, but rather attuned ourselves to what emerged. ${ }^{9}$ At the same time lab experiments inspired us. From them we took the suggestion that if you carefully organize an event, reality may be afforded to act (speak, smell, taste) in novel ways. ${ }^{10}$

There is an obvious resonance here with the breaching experiments favored in (a small corner of) sociology. These were set up to elucidate "the ordinary" by disrupting it. In some daily life settings the experimenters would provoke a crisis by behaving in an unfitting way. They might dress in a bikini in winter; refuse to pay more than half the set price in a restaurant; carry a forbidden object when passing airport security. How did bystanders respond? They were confused. All too often they got mad. "Eating with fingers" might easily be organized as a breaching experiment, too. Here is the student assignment: join a decent Western family for dinner (your own, if that is where you come from; or otherwise one of a friend). Politely say "bon appétit!" and then pick up your potatoes, meatballs and green

9 The experiment as a genre has been amply analysed in the field of Science and Technology Studies. See for examples: Hacking (1983), Rheinberger (1997).

10 For the possible creativity of experiments, see Stengers (2005). The work on experiments that here we draw on most is Despret (2004). 


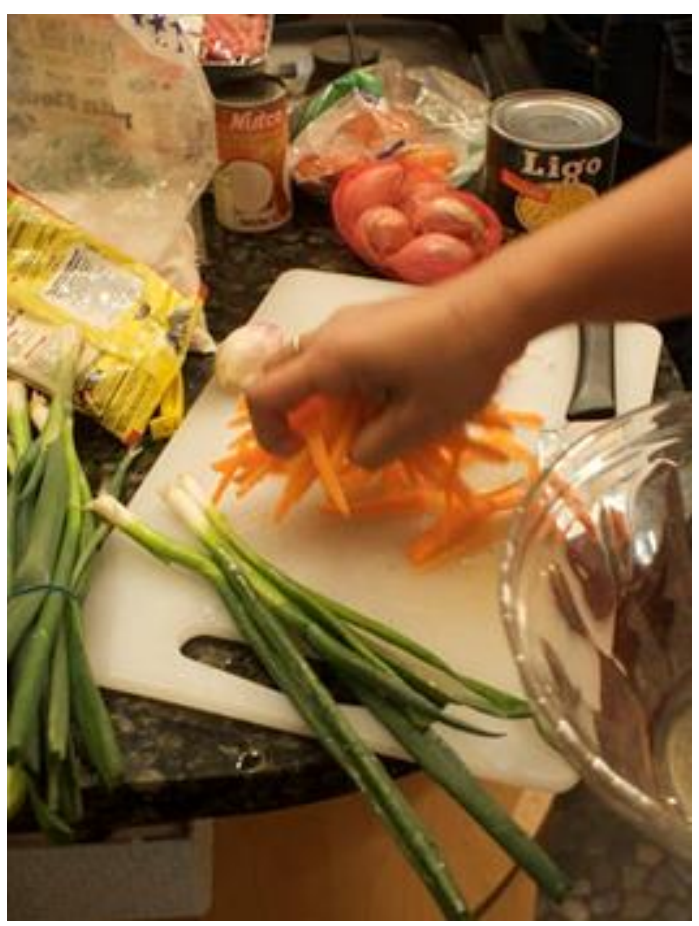

beans with your hands. What happens if you are transgressive in this utterly innocent and yet highly disruptive way? If you keep a straight face, as you should, things may easily get out of hand. "Enough of this!" (if it is your family). Embarrassed postures (if you are a stranger). Things got out of hand in a lot of breaching experiments. The students sent out with assignments quickly began to refuse to disrupt yet more ordinary events by transgressing their rules."

$$
\text { In comparison, }
$$

our experiment was easy. Everyone present was in on the game. But a more important difference from breaching experiments was that ours had another objective. We did not seek to disrupt the rules that make social practices hang together. Our object was not "society" but "bodies." What are the bodily specificities of eating with one's hands? To answer this question, the novices had to be open and adaptive. For the experts, finger eating was altered, too. ${ }^{12}$ They had to attend to and be articulate about things that usually go without saying. There is a methodological proximity to phenomenology here. But phenomenologists take it that bodily experiences form an "existential ground" that precedes "culture and self. ${ }^{13} \mathrm{We}$ took it that a specific configuration of bodies arose from the occasion. The experiment staged reality. It staged a strange bodily practice (for the novices), or staged a familiar practice in a strange way (for the experts). Playing with the familiar and the strange is one of the techniques of anthropology. Anthropologists who set out to study "strange cultures" sought to make these familiar, first to themselves (through extensive fieldwork) and then to their readers (by writing in compelling ways). Anthropologists who study "familiar cultures" have developed the inverse strategythat of artfully alienating themselves from what otherwise may appear to be

11 The classic breaching experiments were instigated by the founder of ethnomethodology, Harold Garfinkel. For a recent example-notably that of passing of airport security with a bottle of clear water to then be confronted with scared and angry fellow passengers, see Woolgar (2008).

12 Writing this text added to the transformation. Or, as Nasima put it in an email message to her co-authors once we had submitted the article: "Finger eating will never be the same again.”

13 The terms come from Csordas (1995). Csordas did a lot of work to make space in anthropology for "the flesh" next to symbolic analysis. We are indebted to this tradition and at the same time hope to shift it. 
unremarkable. In our experiment we combined these ways of working. Mixing them, we drew on the techniques of "making familiar" and "making strange" at the same time.

But however anthropological this may be, we do not read "our" event as symbolizing or otherwise speaking for a culture hiding behind it. ${ }^{14}$ This does not imply that ours was an isolated event, crafted from scratch. Tonight's oral extravaganza was in silent conversation with other texts, films and recipes. We obviously drew on a wide variety of resources, but we freely adapted them to the occasion. I liked our meal, but eating with fingers at home is completely different. At home we don't have tables! Our concern is not with the patterns, systems or structures that make up a "culture" and neither did we stage a "cultural encounter." The experts variously share, and do not share, languages, religious upbringings and cooking styles between them. They have travelled from Indonesia, Bangladesh and different regions of India to further their academic training in the Netherlands. The novices, in their turn, come from the United States, Austria and the Netherlands. We might detail our ancestral lines, regional roots or upbringing. But we won't. These backgrounds are all unmistakably there, they are absent/present in the event and emerged in our conversation. ${ }^{15}$ But we do not aim to attribute our responses to our national or regional cultures. Instead, we aim to situate our responses within the context of our experiment. And rather than seeking explanations, we hope, more modestly, to articulate what we staged. ${ }^{16}$ Such articulation is difficult enough. It is notably hard to put into words what phenomenologists call a "somatic mode of attention." ${ }^{17}$ But maybe phenomenologists make things too difficult for themselves: they seek the somatic, as if "the body" were a universal. Here, our experiment may help. "The" body that we talk about is not universal, but situated. This is our question: what, when one eats with one's fingers happens to taste? Not in general, but somewhere quite specific. In our case. ${ }^{18}$

Before we move on to the event itself, one last note on mixing methods. This has to do with what is work and what is not. We hoped to learn from and write about our experiment and in that sense it was academic work. But jointly cooking a dinner and then sharing a meal do not resemble experimental practices in whitewashed labs. Messier than that, they feel rather personal and intimate. The overlap between work and not-work forms a common concern in anthropology. Even when researcher and informant are different individuals the problem is unavoidable: the researcher gets involved in the day to day life of her informants,

14 The classic model would be Geertz's (1972) analysis of the cockfight as an event from which he could "read" a lot of "Balinese culture" as this was expressed in it.

15 For the notion of absence/presence used here, see Law (2002).

16 This is in line with other recent work in anthropology where descriptions no longer target cultural systems, but tell about specific events, that, interesting in themselves, can be made to index a variety of things at the same time. See for a great example Raffles (2010).

17 The terms "somatic mode of attention" comes from Csordas (1993)

18 Case knowledge does not spread in the form of generalisations but, as it spreads, gets translated and adapted to ever new sites and situations. See Mol (2008). 
while, in doing so, she gives shape to her own life as well. Where, then, does "work" begin and end? Our experiment was similarly ambiguous. Most of us hardly knew each other before the event. But in the days that followed, we exchanged warm and grateful emails. "Thank you for the lovely evening," we wrote. It was heartfelt. While we addressed our research questions, other realities were present as well. On this evening there was fun, food that tasted good, and enjoyment. What came into being was a little piece of what, all too widely perhaps, might be called "the good." Questions of method are implied here. How to foster research practices that afford rich and layered realities? How to make space for analysis as well as care? And how, finally, to keep complexities, ambiguities, tensions and pleasures alive in one's writing? Mixing methods calls for inventive writing styles. ${ }^{19}$

\section{Viscous foods}

We set out to explore what happens to taste when you eat food with your fingers. But which foods would be instructive? Here, the issue was not that we had to select "representative" foods. We were not studying an object that our foods should-or could-represent. Instead, the issue was that we were out to explore tasting with fingers. I eat sandwiches, pretzels and fruit with my fingers every day. Dishes as easy to deal with as sandwiches, pretzels and fruit would not do the trick, although we did include one of these in our meal. I was worried that I could not do it, rice with my fingers. That I would get nothing to eat. Then Amalinda and I chatted in the corridor and I was reassured. "I am thinking about what to cook. You know what, I will cook something for you that is not too difficult. Something my fouryear-old son can manage as well." Amalinda made bakwan. She chopped carrots in fine stripes, added corn kernels, spring onions, flour, an egg, spices and water. With this batter she deep-fried what looked like small pancakes. Once cooled down a bit, they were easy to handle. And they tasted great.

This, however, while soothing, put neither skills, nor tasting to test. Our other dishes were therefore less solid. Take the khichuri (in Nasima's Bengali) or khichadi (as Priya called it in Marathi) that they jointly cooked. Mustard oil in a big

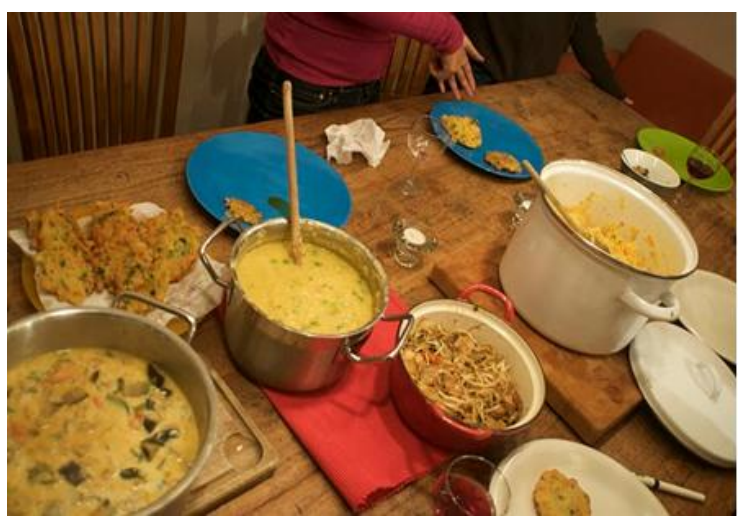
pot-chopped onions and garlic, stirred until they turn golden brown-cumin seeds, curry leaves, cut potatoes and tomatoes, grated carrots with chili powder, ginger powder, soaked basmati rice mixed with moong dal (a kind of lentils) and water-put the lid on, churn and check periodically until it is semisolid.

19 In science studies as well as in feminist scholarship there used to be room for a variety of styles. But just like in anthropology there, too, experimental styles seem to disappear. Maybe this is due to ever more institutional pressures. Maybe such styles can only thrive in combination with other experimental efforts. See also Marcus (2007). 
The small lentils used in this dish fall apart and dissolve among the grains of rice. This results in a viscous stickiness, more difficult to transport from plate to mouth than bakwan, but easier to handle than plain rice that, for all its dryness, falls apart. Adding yet more fluids makes things more difficult again. Malini's dal was a case in point: lots of lentils, with fresh peas, tomatoes, cumin, fenugreek and ginger, cooked in ample water. It was not easy to pick up. Most difficult to handle were the two dishes that did not form a viscous whole, but where solids were suspended in fluids: Malini's eggplant curry and Amalinda's soy dish, composed of soft tofu cubes, unruly soy sprouts and utterly fluid kecap manis-a soy sauce that is sweet.

All these foods called for appropriate bodily techniques. ${ }^{20}$ When it comes to moving the flavorful fluids on my plate to my mouth, I find I have become better adapted to the prosthesis of the fork, than to my own fingers. No natural bodies here, only adapted ones. Thus, for those of us whose bodies are adapted to utensils there are bodily techniques to acquire. There is food on my plate. Now what do I do.? Malini has mercy: "So, you join your fingers. You put them together tightly, like this." She gives a demonstration, pressing khichuri and dal together again and again. Then she lifts a small ball up on her fingers and uses her thumb to gently push it into her mouth.

This was unplanned. At the dinner table, half of the fun was missed because of the zealous instructors. Before we could watch how the Westerners handled the semi-solid, fluid food with their fingers-we began to instruct them. Momentarily the novices came to be called "Westerners." Crafting a division in this way, to then point out the clumsy gestures of those who have learned to celebrate their table manners as a sign of Civilization, may be fun for good historical reasons. When I met Amalinda in the corridor she said: I look forward to our experiment. I look forward to laughing at you! But once we had started, the experts didn't laugh. As we began eating, the experts started handing out compliments. "Yes, that's how to do it. Very good." In this way the novices are put in the position of children who do not yet know how to eat. Excellent. Turn them into children. An old trick, extensively deployed by colonizers just a few decades ago. At our dinner table expert superiority was performed in a way that is both more gentle and more vicious than laughing out loud.

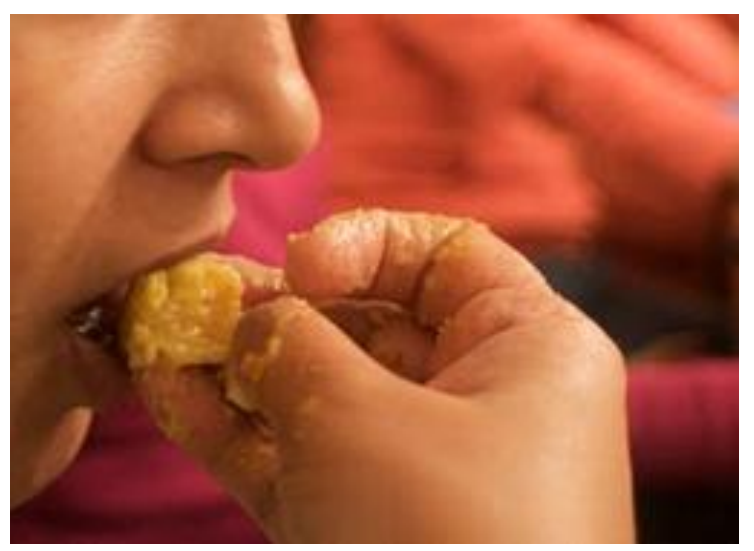

"Very good, Anna!" Malini compliments again. I can't enjoy the compliment. "But my muscles, I feel sore already! My shoulder. . . ," I start complaining. Priya gives more explanations, "You are holding your elbow too high. You can rest it on the table." Malini adds: "Well, actually you shouldn't. Most of the time you shouldn't. . . But we do it

20 The techniques involved in eating with fingers are "bodily techniques" in the sense of Mauss ([1935] 1973). 
anyway." Mastering eating with fingers does not just involve lifting food to your mouth. There is a lot more to it. If you want to avoid a sore shoulder, you should not hold your arm too high, nor tense up your muscles. And then there are rules about what is and what is not appropriate. Civilization comes in versions. Using fingers is not necessarily liberating. There are rules governing the specific use of fingers. Where I come from, this is not considered graceful: fingers dropping food from the mouth, food moving beyond the proximal meta-tarsal joints, fingers moving food outside the plate, fingers joining in a fist so as to put food into the mouth. Teaching the fingering of food goes hand in hand with disciplining the eater. In this disciplining one rule presides and here food taboos come in: only the fingers of the right hand are involved in eating. What goes into the body must be kept separate from what goes out. Do fingers get "dirty" from handling food? No, that is not the word. ${ }^{21}$ The left hand is "dirty." When Emily moves with her left hand in the direction of her food, she is told off. Thus, our left hands were left to linger and did not eat.

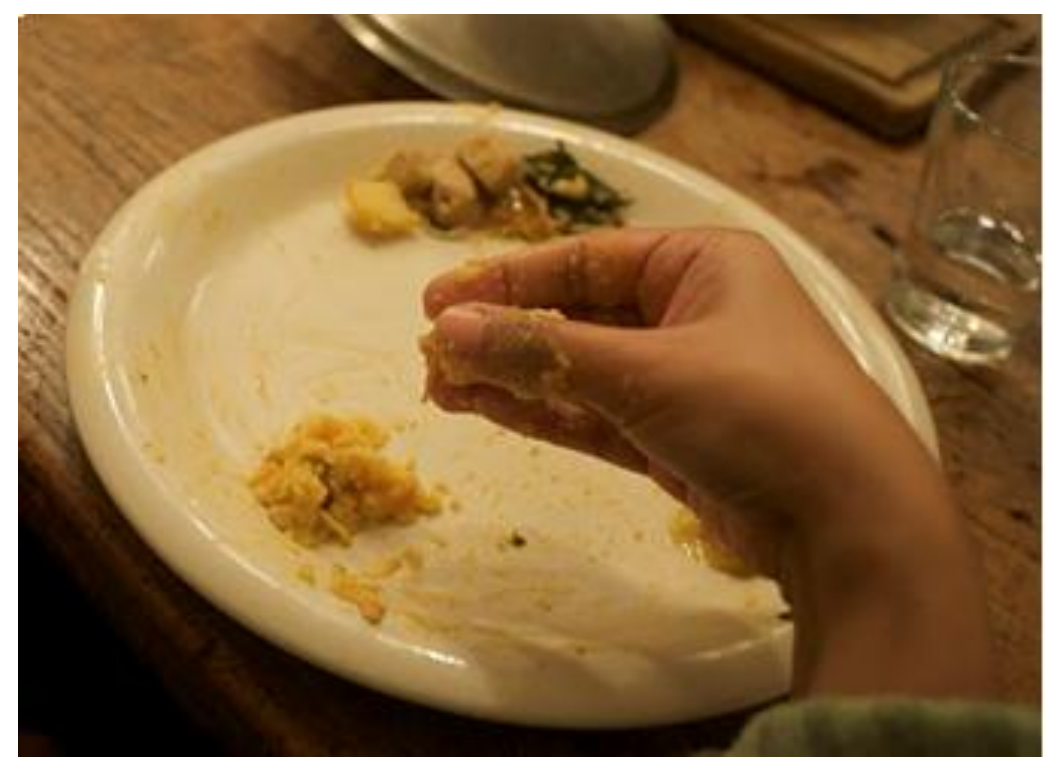

But whether easy or difficult, handled appropriately or not, in our experiment the primary relevance of eating viscous food with fingers lay in its effects on the practice of tasting. When you eat with your fingers, you mix the dal and the rice, you mash it. You press it together. You get a different consistency. With a spoon, you could never do this! There it is: a pivotal moment in the experiment. The fingers do not "pick up" viscous food from the plate as it is, but they handle it on the plate to then lift it. Malini shows how she deals with a small potato part that she separates out from the khichuri. It is small enough to be inserted into one's mouth just like that. But Malini crushes it first, on her plate. Thus, she says, it acquires more taste. How? It may be that such crushing makes the qualities of various foods

21 Or maybe it is, sometimes. In Indonesia, says Amalinda, it is jokingly said that the hands add vitamin $\mathrm{K}$ to the food-K for kotoran, dirt. And the man working in Anna's favourite Indian take-out in Vienna tells her cheerfully that food tastes different when eaten with fingers because the bacteria on the fingers already start to digest it. 
more available to a sensing body. It may also be that the potato, while being crushed, soaks up some of the flavorful fluids around: those of the dal, the eggplant curry or the kecap manis, depending on how you have distributed the various dishes on your plate and how you move your bite-to-be between them.

Either way, eating with fingers does not just index an absence of metal or plastic intermediaries, while everything else stays the same. ${ }^{22}$ Something else is going on, something more intriguing. As I handle my food, the tasting does not start once the relevant "sense data" have reached nostrils and tongue. There is already "tasting" going on while my food is still on my plate. As my fingers squeeze and mash, I look forward-taste forward-to what my mouth will come to appreciate in a moment. This is not to say that the fingers are a starting point, that they do the tasting. ${ }^{23}$ Instead, they are part of a virtuous cycle. As the fingers move, the mouth anticipates. As the mouth anticipates, the fingers work. Perception does not follow preparation, but comes to be viscously mixed up with it. ${ }^{24}$ Fingers and tongue work with mathematical precision, the fingers mash and roll little balls of rice and lentils, that then find their way into the mouth and while the tongue rolls and works with the teeth, the hands get working again as well-mixing, rolling and mashing the food, and placing it once more in the mouth. Tasting, or so we would like to suggest, is not confined to a single moment. It is actively being done throughout this entire process.

\section{Appreciation}

As the fingers of the right hand mix and mash food on a plate, they are involved in tasting. But what does this entail? The English term "tasting" encompasses two different (if related) kinds of activities: perception and appreciation. You will come across various perceptions below-for instance that of the warmth and the stickiness of the food. However, we will not explore the recognition of this or that flavor, but foreground the appreciative aspects of tasting. ${ }^{2.5}$ The foods that are tasted

22 Our concern is with what the fingers come to do rather than with the absence of utensilmediators. We do not pursue a dream of un-mediatedness and authenticity (see for an analysis of such dreams van de Port 2011). The bodies in our stories are not pre-lingual either, if only because their appearance in the present text is dependent on our verbal planning, our conversations during and after the event, our notes and our analysis. For the relevance of dinner table conversations for taste, see Wiggins (2002).

23 What fingers do as they mix and mash the foods on a plate, may also be typecast in other ways. Janeja, in her study of Bengali food practices, talks about "chewing with the fingers" (Janeja 2010: 59) (we thank one of the reviewers for the reference). Thus, it appears again that bodily "functions" may spread out in different ways over a body and its surroundings. Cutting, for instance, may also be called chewing while cooking may be called digesting. What are the effects of situating tasting, chewing, digesting, excreting, etcetera, in one bodily-cum-social site or in another? Here, we do not answer that question but merely suggest it deserves to be posed.

24. For earlier work that re-describes perception is an activity rather than an experience, see Hennion (2007), Hennion and Gomart (1999).

25 Western epistemology is marked by attempts to separate facts from values and, as a part of that, perceptions from appreciations. This separation is difficult to make for tasting and smelling. This has always put them low on the hierarchy of the senses (see Korsmeyer 1999). 
are important here. With some effort, the experts managed to assemble most of the ingredients crucial to cooking "foods from home." The Pakistani shop hidden along a side street of Amsterdam had the right kind of pickles to spice up the meal. It had mustard oil and even fresh curry leaves. ${ }^{26}$ These days ordinary Dutch supermarkets sell lots of products that were, until recently, unknown in these corners of the world. Thus (at least if you have the money) delicacies such as basmati rice, eggplant, coconut milk and chili peppers are easy to come by. Kecap manis (as it comes from the Netherland's former colony Indonesia) is no problem at all. But ingredients are not enough. You also need to be able to cook. I took up cooking at a very early age out of need but I never liked it. Now, cooking is my stress buster. I meditate as I chop vegetables, each piece as perfectly cut as possible. I carefully feel the texture of food. If I am making dough for the rotis, I know how the rotis will taste to the mouth based on how the dough feels on my fingers.

If need be, or when given a chance, fingers become involved in tasting even before they handle food on a plate: as they chop, as they knead, as they cook. In our experiment, too, there was tasting in the kitchen. We rubbed the fresh curry leaves between our fingers and then smelled them. We compared organic and non-organic tomatoes. This one is better! No, are you kidding. . . . This one has more taste! Appreciations differ. For however important the food, the appreciating person is vital, too. We each brought different expectations to our dinner table. The khichadi did not turn out the way it would taste if I took all the seven women to Mumbai and make my mother cook it for them. The experts brought in dishes that evoked memories of their various homes. For the novices everything was new. Or was it? $?^{27}$ I add a little bit of the pickles, because the dal is not spicy enough. At least to my taste. I find the dishes not particularly hot. Malini comments: "Anna, I am impressed by your resistance to chilies!" I am proud. When cooking Malini added quite a lot of fresh chilies to her curry. But she took some of them out after having invited Emily and Annemarie to taste. They thought the dish was getting too hot. As "too hot" is the appraisal expected from her, Anna takes prides in her "resistance" to chilies. Elsewhere eating chilies is not a matter of pride. Many poor people on Java, Indonesia, feel that without chilies they have not eaten. They spend their money on hot peppers even if they have too little rice. Appreciation depends on adaptation.

Appreciating the food one eats, this much is clear, is a complex achievement, thick with global and personal history. But now back to the fingers. What is their particular relevance to appreciation? Here, again, memories of home may come in. Even if you only have modest dishes on your plate, such as just vegetable dishes (back home in Indonesia a good meal would contain meat or fish), if you eat together with your family and if you are happy about being together, food will always taste better. Finger eating may provide pleasure because it evokes fond memories of home. But not for everyone. In the families of the novices finger eating was not done. Well. Let me tell you: I liked it. I enjoyed this substantive contact of fingers and food. Feeling the warmth of what I was about to eat, no, what

26 A lot is written on food mobility. See for an example that resonates with our case Mankekar (2005).

27 For an analysis of current taste travels and mixtures, see Wilk (2009). For a critical note, with the example of Thai food, see Heldke (2008). 
I was eating. Its substance, its stickiness. Even if as a child one has been taught to avoid sticky fingers, one may like such stickiness later on. The transgression of social norms may be part of the pleasure. But a positive appreciation of finger eating is not a "natural" response. I find it awkward, mushing the food together, and feeling it slide down my fingers. Yes, there is something that feels fun-what a mess I make! And yes, it also feels good to make the slurping noise as I inhale the food that would otherwise fall on my plate. But it also feels illicit. This is awkward to write, since I recognize the ghosts of colonialism within the feeling, but it feels primal-animal-like, or even anti-human. There they are again: global as well as personal history both, irretrievably intertwined, absent/present at our dinner table. What can you do? Write it down. The experiment, after all, is meant to ruthlessly explore.

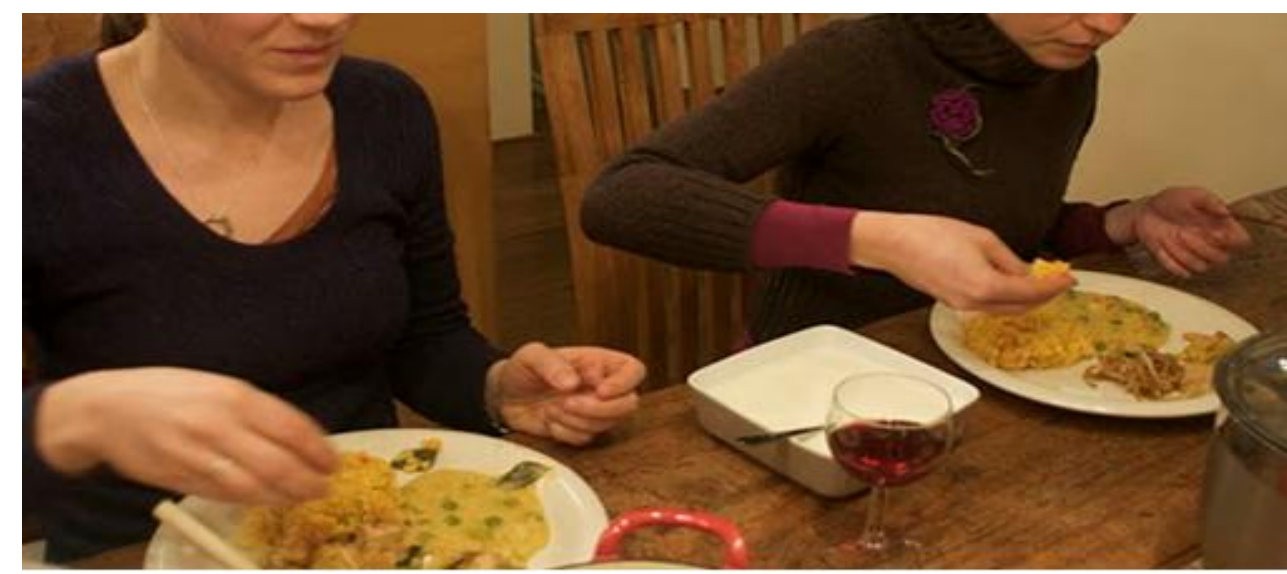

\section{Bodily substance}

The pleasures and ambivalences evoked by finger eating are not just a matter of social norms that one complies with or transgresses. Finger eating is also fleshy. It stages a physical proximity between the person eating and the food that is being eaten. By using fingers there is no "distance" between your food and yourself. There is no "gap" such as spoon or fork while eating. You get mixed up with your food. I believe this makes food taste better. Recognizing the resemblance between fingers and food depends on foregrounding the substances involved. This may be done variously. When it is eaten with the fingers, food is performed as proximate. Somehow, it is just like I am. I am like the food is. We already share our being as a specific kind of physical substance before I have chewed, digested and absorbed what I eat. It is not that "I am rice and dal" nor that "rice and dal are me" but that, somehow, jointly we partake in a larger category. The appreciation brought out here has little to do with what (so far) the English term "tasting" connotes. But which other terms might we use to talk about it? It seems that acknowledging the physical kinship between oneself and one's food may bring a devouring kind of joy. ${ }^{28} \mathrm{~A}$ cheerful recognition of shared vitality. I am alive! How to write this without

28 Sartre, one of our reviewers teaches us, has written an essay on stickiness (in Sartre 1943), where, we quote the reviewer, "he reflects on viscosity as unstable, an aberrant 
suggesting that, despite our earlier caveats, we are in nature here after all? It is all rather elusive. Eager to still articulate this aspect of our event, we grope for words. And this is our suggestion: to stretch the term and include this vitalist, appreciative encounter between fleshy fingers and physical food in the term "tasting."

Another dimension of pleasure is also at play. As fingers engage in a sensuous contact with food and appreciate its warmth and stickiness, the body itself is being touched as well. Take for instance the licking of the fingers. Nasima shows how to do this while visibly enjoying it. The licking does not only bring food into the mouth, it also is a way of sensuously touching the fingers. This gets all the more pronounced as we are having dessert. Nobody thought about preparing a dessert, but Malini bought yoghurt to calm, if need be, the heat of the chili. She went for the relatively fluid Dutch yoghurt that is sold in one liter containers and a lot of it is still left after we have finished our main course. We each pour some on our plate. Emily brings honey to the table, which we add. But eating honeyed yoghurt with one's fingers is not a matter of preparing and lifting up a small portion, pushing it into one's mouth and maybe licking away a few sticky remnants afterwards. Instead, it involves dipping one's fingers into the white stuff, hoping it doesn't all fall back when lifted to the mouth-and licking. The yoghurt may taste good; the honey may be delicious. But the licking itself can be pleasurable, too. As we were eager to not embarrass each other, we did keep some things backstage. What we did not discuss (it is important to also note what remained unspoken) was the eroticism of eating with fingers. It may have remained unspoken then and there, during the event. It was, however, written down in our notes afterwards. Variously. The contact of finger, food, lips, tongue, teeth and mouth is evocative of erotic imageries and sensations.

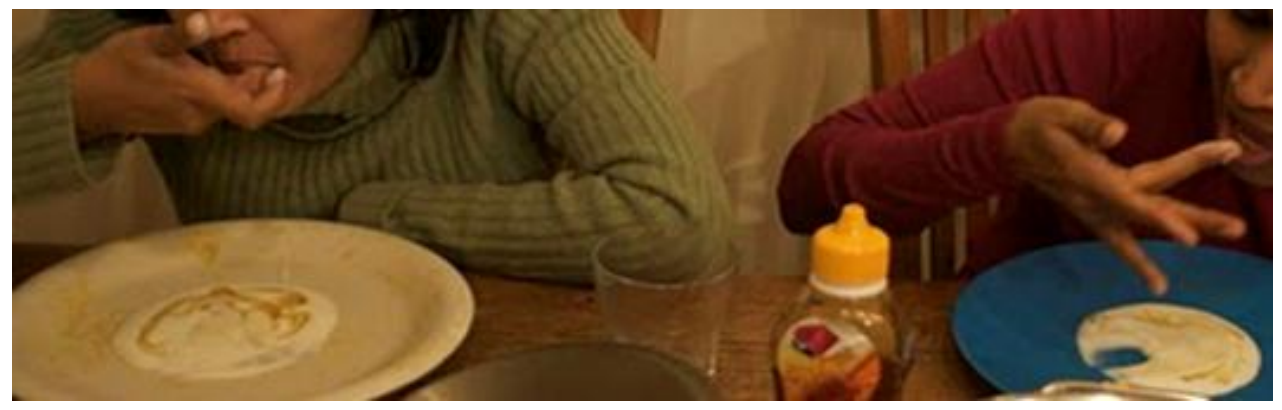

fluid or melting solid that attacks the boundaries between myself and it; to touch stickiness is to risk diluting myself into viscosity." Thus, to Sartre "diluting myself into viscosity" indexes a risk, a potential loss, something dangerous. This interestingly contrasts with our "bodily experiences." At least those of us who made notes about the topic (as it happens one expert and one novice), did not mention dangers and risks. Instead, we noted that the fluidity of the boundaries between ourselves and our food was pleasurable. Wherever this difference comes from, it indicates that the "me" that Sartre evokes as if it were a generality, is indeed just that: a me. Phenomenological studies on "the body" more generally deserve to be read as first person singular ethnographies. 
Is it good? Yes. Or no. Or both. The illicit and the pleasurable, the devouring and the vital, the erotic and the embarrassing. It is not always clear how to separate these out: they are viscously enmeshed. And there are yet more bodily sensations involved. Take what the stomach and bowels feel after one has eaten, what nutrition scientists call satiety-but this is not the word we seek. What to say instead? Fullness? Belly feel? Here is a suggestion: stomach taste. I do not think of-or care for-digestion much in my daily life. I do not have a rich vocabulary for describing fullness. I do not know when my stomach is one third full or two thirds full or when I have taken away all of the air intended for burping. The experts already talk about digestion while cooking, pointing out which spices aid digestion. The pleasures and pains of defecation also make their way into our conversations. And we talk about how to avoid eating so much that mouth pleasure leads to bowel pain. $^{29}$ I have one weakness though, something that I was punished for as a child. I do not understand when I have had enough food and I don't need any more. I tend to eat more, I enjoy eating more. But then I feel uncomfortable and I suffer that sensation of uneasiness. My mother looks at me, "I warned you before. When will you learn to read your stomach? Now here are some roasted ajwain seeds with salt. Eat these and you will feel better."We did not have any ajwain seeds, nobody tried to find those in Amsterdam. This was no problem for the novices, who didn't know how to feel a need for them. Some of the experts, however, complained that they felt bloated. I told Malini that having studied dieticians for years I first thought that eating-with-fingers might be propagated as a technique for eating less. But as she felt too full, she had "disproved my hypothesis." Malini laughed and said teasingly: "Yes, clearly, because eating with fingers makes food taste better."

\section{Conclusion}

Eating, teaching, tasting, learning, digesting, licking, longing for the food one is about to receive from one's fingers: they all flow into, and help to shape, each

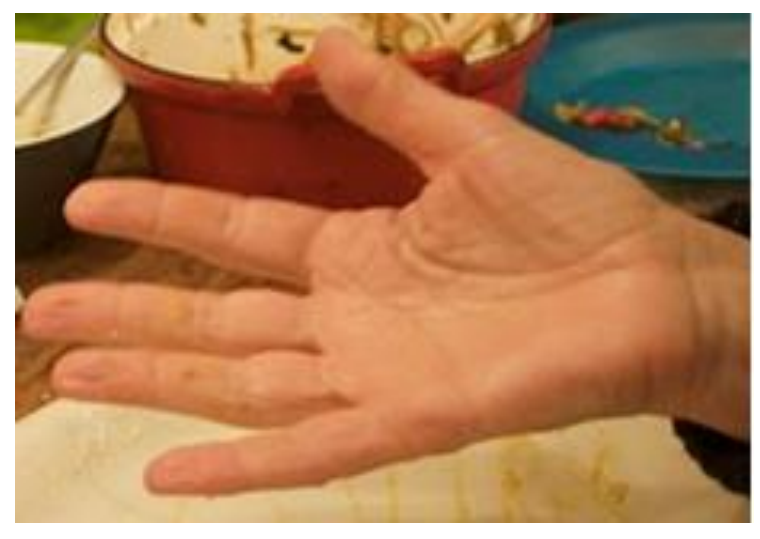
other. The process is not linear, instead now, before and after get mixed together. And yet at some point the experimental meal is over. $B y$ the end of the meal the fingers of my right hand-the eating hand-feel like they have been wet for too long. The skin has crinkled up, just like when you are in the bath or the swimming pool for ages. They

29 The question when, where and to which extend the quality of food may best be specified by talking "taste" is to be explored. For satiety as well may give satisfactionand for those able to subtly feel it, this may come in a diversity of shades. In parts of West Africa, for instance, the specific belly feel of fu fu is appreciated over that of other foods; see McCann (2010). In Bengali, a language derived from Sanskrit, Nasima relates, a good meal (feast) is partly defined by the way one ingests it. A good meal involves all these modes of ingestion food: chewing (charbo), sucking (chushsho), licking (lejjho), and drinking (peyo). Again: a lot left to explore. 
get a bit cold, too, from being wet. Thus, even when they are no longer actively involved in tasting, the fingers remain caught up in it. It takes a while before they dry out.

Priya tells us that it is a good sign if the hands dry all by themselves after dinner. As a rule nobody leaves the eating circle as long as somebody else is still eating. But dry hands indicate that the family has remained assembled, still chatting on, even after everyone has finished eating. Such sociability is laudable. In our experiment it is easy to be sociable, stay put, and talk. There is so much to talk about. Families. Mothers. Children. The caring tasks of women. The various ways in which each of us escaped the fate of a life that circles around preparing meals and feeding others. And there we are: studying tasting fingers. Food may well be a risky topic for women academics, long before the touchy sensuousness of fingers comes into play. After all, food (at least in its mundane daily life version) is all too widely considered to be "women's business." But then again: someone should attend to it. Like air and water, food is all pervasive-it lands on plates-banana leaf, porcelain, paper or plastic-in Tura, Xiamen, Bali and Bogota.

So what have we learned? There are a few lessons. The first is about civilization. We ate without the utensils that a long time ago differentiated Parisian court life from neighboring peasants and then came to differentiate between a Western "us" and its Oriental "others." However, at our dinner table it quickly emerged that eating with fingers is not unruly. Instead, it comes with its own set of norms-or with different sets of norms in different places. This reiterates an old lesson of cultural anthropology. Rather than going through a single "civilization process" humanity developed many civilizations. Many cultures, as they have been called. But these are not solidly integrated or structurally fixed. This allowed us to draw "eating with fingers" out of its original context(s) and to move it to another: our experiment. We treated it as a mobile repertoire. This helped us to explore an aspect, or a version, of what it may be to taste. At the same time, our method, however original we made it seem, may well reflect an ordinary fact of present day global life. Repertoires get disentangled from their contexts, moved around and pasted together variously, all the time. Thus, in Jakarta one may eat rice and its sauce with one's fingers, but yoghurt with a spoon. Or one may use a spoon when one is sad or in a hurry, while eating with one's fingers in more quiet and happy moments. ${ }^{30}$ In Dakar finger eating may be preferred, but people with diarrhea will use a washed spoon to eat fluidly mashed rice (jau) from a plate as their fingers are not to be trusted. And in the restaurants of Amsterdam knife and fork may predominate but Chinese (or Vietnamese or Korean) dishes are eaten with chopsticks and Mexican tacos (or American hamburgers or Italian pizzas) with fingers. ${ }^{31}$ This is the (always only partially) post-cultural state of affairs. As repertoires get drawn out of their corners and juxtaposed in novel ways, there are

30 When Amalinda described our experiment to her family in Indonesia, her sister laughed out loud. Why eat yoghurt with fingers, a spoon is a lot easier! Why not mix repertoires as seems fit? For the notion of repertoires that, even if they stem from different traditions, may be mixed, see, with the example of counting, Verran (2001).

31 The Chinese branches of Pizza Hut offer parties where the children are allowed to make their own pizza and then get a lesson in Western modes of eating-with knife and fork. (Or so one of us witnessed in 2010 when traveling there.) 
new interferences, unexpected effects. Mixing, then, is more than just a method. It also resonates with a specific feature of the global condition, where complex boundaries coexist with endless interferences and nothing ever comes to rest. ${ }^{32}$

At our Amsterdam dinner we have not learned anything about either the nature or the culture of tasting "as it is." Experimentally generated facts always depend on interventions that, involving artifacts, are literally artificial. ${ }^{33}$ So, too, here. Thus, we do not claim that our experiment has taught us lessons about "tasting" as if this were a pre-cultural phenomenon. But neither did we learn about the way that this, that or the other "culture" shapes what it is to taste. Instead, the event we staged depended on a mismatch of socio-material bits and pieces with highly divergent provenances: our joint presence in Amsterdam that we owe to various grants as well as global inequalities and other features of current academic life; foods that had travelled long routes in ways that are new compared to even twenty years ago; old recipes and skills mobilized to prepare our dishes; the kitchen, the warmth of the apartment while it was freezing cold outdoors; the size of the table; the money that paid for our grocery bills; our personal freedom to engage in this dinner. Early theorizing about "situated knowledge" in feminism insisted on the situatedness of the researcher and her modes of knowing. ${ }^{34}$ What we seek to draw out here is that reality itself is situated, too. The variant of tasting with fingers that we write about, emerged in a specific setting. A one-off event in combination with our research questions and theoretical sensitivities, informed by the state of the academic fields in which we hoped to interfere.

What did we learn about tasting in this specific site? We started out from Malini's remark that when you eat with your fingers, foods taste different. Throughout this text we presented lessons about our tasting efforts, in story-format, along with the situations from which they emerged. Can these lessons be drawn out? Let's give it a try. It is clear that our dinner was not the same event for each of us. For the experts there was a challenge in articulating the familiar; for the novices finger-eating was a transgression-pleasant, awkward, or both. But what we managed to establish jointly was that in the specific setting that we created, tasting fluidly spread out in time. It was not confined to a moment. As our fingers mixed and mashed foods on a plate they were preparing a tasty bite, while the mouth, longingly, coached the fingers. Tasting, anticipated and cared for in the kitchen, even goes on after the food has been swallowed and made the belly feel good, or perhaps too full. Thus, it makes a difference to "tasting" that we did not just sample food to test it, but prepared and ate it, too. ${ }^{3.5}$ For in this way our appreciation started before bakwan, khichuri, dal, eggplant curry and mixed soy

32 See, for the spatiality implied Massey (2005), and for a closely related argument Tsing (2004).

33 For the argument that labs fabricate facts, see Latour and Girard Stark (1999).

34 The reference is to Haraway (1989). Haraway, too, has persistently brought out the specific timeliness of the objects of science-be they monkeys studies in cages resembling U.S. suburban families of the nineteen fifties, or the genetically purified onco-mouse.

35 Wine tasters, for instance, isolate "perception" and spit out the wine they taste. See Mann (2011)for a more carefully exploration of how this affects theories of tasting. 
dish had reached our tongue and continued after we had swallowed. As our fingers mixed and mashed the food and then lifted it to the mouth, they sensed its physicality, not so different from their own. Thus we encountered our vitality-we tasted it. And, finally, as we licked our fingers the body's fleshy character transpired again, allowing, this time, for yet a different pleasure: the sensuous pleasure of being licked and licking. Not each other's fingers, but our own.

It may seem overdone to call that sensuous encounter of fingers and mouth tasting. It is after all perfectly possible to say that in finger eating touch comes in to complement taste. But when we try to stay close to what happened during our experiment we are not inclined to say that. Why keep the senses apart and the terms stable as if they all preceded the event? Instead, the creativity of experimental methods is in their ability to configure reality in an original way. Rather than linking causes and effects so as to create predictability, ethnographic experiments generate unprecedented possibilities. This calls for linguistic strategies that do not start out from dictionaries, but are, instead, inventive and help to say and sense new things. In relating our experiment, then, we care to stretch and twist the term "tasting" to adapt it to the situation at hand. May we thus interfere in the English language? Who is allowed to bring in new cases, new events, and adjust not just theoretical terms, but the English language itself, so as to fit these added exemplars? If we were granted that right, we would like to suggest that "tasting" may include being appreciative of the warmth and the texture of what, when eating with one's fingers, the fingers sense. That it may include anticipation during cooking and satisfaction afterwards. And that even the boundaries between appreciating one's food and appreciating one's body may get blurred. If we propose this, we do not claim to state a general truth about "the" human body, nor about eating or tasting in all times and places. But if the situation affords it, if the circumstances are just-so, mashing, licking, chewing, digesting and absorbing food may viscously spread out and get mixed up, not just into each other, but also into appreciating one's own stunning vitality. Human bodies, after all, are alive, for as long as they last, thanks to their food. Eating deserves to be appreciated.

\section{Post scriptum}

A few weeks after our experiment, Nasima, browsing the library for other research purposes, came across the perfect quote. Of course our topic was not new to anthropology. Mauss had been there already. "Consumption techniques. Eating. You will remember the story Hoffding relates about the Shah of Persia. The Shah was the guest of Napoleon III and insisted on eating with his fingers. The Emperor urged him to use a golden fork. 'You don't know what a pleasure you are missing,' the Shah replied” (Mauss [1935] 1973).

\section{References}

Choy, Timothy, Lieba Faier, Michael Hathaway, Miyako Inoue, Shiho Satsuka and Anna Tsing. 2009. "A new form of collaboration in cultural anthropology: Matsutake worlds.” American Ethnologist 36 (2): 380-403. 
Csordas, Thomas. 1993. "Somatic modes of attention.” Cultural Anthropology 8 (2): $135-156$.

- 1995. Embodiment and Experience: The existential ground of culture and self. Cambridge: Cambridge University Press.

Despret, Vinciane. 2004. "The body we care for: Figures of anthropo-zoo-genesis." Body \& Society 10 (2-3): 111-134.

Douglas, Mary. 1966. Purity and danger: An analysis of the concepts of pollution and taboo. London: Routledge, Kegan \& Paul.

Elias, Norbert. (1939) 1997. Über den prozess der zivilisation. Soziogenetische und psychogenetische untersuchungen. Erster band wandlungen des verhaltens in den weltlichen oberschichten des abendlandes. Frankfurt am Main: Suhrkamp.

Farquhar, Judith. 2002. Appetites. Food and sex in post-socialist China. Durham: Duke University Press.

Fruzzetti, Lina M. and Ákos Östör. 1984. Kinship and ritual in Bengal. Anthropological essays. New Delhi: South Asian Publishers Pvt. Ltd.

Geertz, Clifford. 1972. "Deep play: Notes on the Balinese cock fight.” Deadelus 101 (1): 1-38.

Geurts, Kathryn L. 2002. Culture and the senses. Bodily ways of knowing in an African community. Berkley: University of California Press.

Gomart, Emilie and Antoine Hennion. 1999. "A Sociology of attachment: Music amateurs and drug addicts.” In Actor network theory and after, edited by John Law and John Hassard, 220-247. Oxford: Blackwell and the Sociological Review.

Freeman, Rich. 2011."Taste.” Material Religion: The Journal of Objects, Art and Belief7 (1): 132-139(8).

Hacking, Ian. 1983. Representing and intervening. Introductory topics in the philosophy of natural science. Cambridge: Cambridge University Press.

Haraway, Donna. 1989. "Situated knowledges. The science question in feminism and the privilege of partial perspective." Feminist Studies 14 (3): 575-599.

Heldke, Lisa. 2008. "Let's cook Thai. Recipes for colonialism." In Food and culture. A reader, edited by Carole Counihan and Penny van Esterik, 327-341. New York and London: Routledge.

Hennion, Antoine. 2007. "Those things that hold us together: Taste and sociology.” Cultural Sociology 1 (1): 97-114.

Higgins, Kathleen M. 2007. "An alchemy of emotion: Rasa and aesthetic breakthroughs." The Journal of Aesthetics and Art Criticism 65 (1): 43-54.

Holtzman, Jon. 2009. Uncertain tastes. memory, ambivalence, and the politics of eating in Samburu, Northern Kenya. Berkley: University of California Press. 
Howes, David. 1991. The varieties of sensory experience: A sourcebook in the anthropology of the senses. Toronto: University of Toronto Press.

Janeja, Manpreet K. 2010. Transactions in taste: The collaborative lives of everyday Bengali food. London and New Delhi: Routledge.

Khare, Ravindra S. ed. 1992. The eternal food: gastronomic ideas and experiences of Hindus and Buddhists. Albany: State University of New York Press.

Korsmeyer, Carolyn. 1999. Making sense of taste. Food and philosophy. Ithaca: Cornell University Press.

Latour, Bruno, and M. Girard Stark. 1999. "Factures/Fractures: From the concept of network to the concept of attachment." RES: Anthropology and Aesthetics 36: $20-31$.

Law, John. 2002. Aircraft stories. Decentering the object in technoscience. Durham NC: Duke University Press.

Law, Lisa. 2001. "Home cooking: Filipino women and geographies of the senses in Hong Kong.” Cultural Geographies 8 (3): 264-283.

Mankekar, Purnima. 2005. “'India shopping': Indian grocery stores and transnational configurations." In The cultural politics of food and eating. A reader, edited by James L. Watson and Melissa Caldwell, 197-214. Oxford: Blackwell Publishing.

Marcus, George. 2007. "Ethnography two decades after Writing Culture: From the experimental to the baroque." Anthropological Quarterly 80 (4): 1127-1145

Massey, Doreen. 2005. For space. London: Sage.

Mauss, Marcel. (1935) 1973. "Techniques of the body." Economy and Society 2(1): $70-88$.

Mintz, Sidney. 1996. Tasting food, tasting freedom. Excursion into eating, culture and the past. Boston: Beacon Press.

Mann, Anna. 2011. "Spitting out or swallowing? On 'taste' and bodies that qualify food and drinks." Paper presented at the workshop: "Eating Bodies and Places.” University of Copenhagen, Denmark, April 13-15.

McCann, James. 2010. Stirring the pot. A history of African cuisine. London: Hurst and Co.

Mol, Annmarie. 2008. The logic of care. Health and the problem of patient choice. London: Routledge.

Mol, Annmarie, and John Law. 2004. "Embodied action, enacted bodies. The example of hypoglycaemia.” Body \& Society 10 (2-3): 43-6.

Perrin, Tessa, Hazel May and Elizabeth Anderson. 2008. Wellbeing in dementia. An occupational approach for therapists and carers. Second edition. London: Churchill Livingston Elsevier.

Pols, Jeanette. 2005. "Enacting appreciations: Beyond the patient perspective." Health Care Analysis 13 (3): 203-221. 
Port, Mattijs van de. 2011. Ecstatic encounters. Bahian candomblé and the quest for the really real. Amsterdam: Amsterdam University Press.

Raffles, Hugh. 2010. Insectopedia. New York: Pantheon Books.

Rheinberger, Hans-Jörg. 1997. Towards a history of epistemic things. Synthesizing proteins in the test tube. Palo Alto: Stanford University Press.

Sartre, Jean-Paul. 1943. L'être et le néant. Essai d'ontologie phénomenologique. Paris: Gallimard.

Seremetakis, C. Nadia. 1996. "The memory of the senses. Part I. Marks of the transitory." In The senses still. Perception and memory as material culture in modernity, edited by C. Nadia Seremetakis, 1-18. Chicago: University of Chicago Press.

Serres, Michel. 1985. Les cinq sens, philosophie des corps mêlés. Paris: Grasset.

Stengers, Isabelle. 2005. The invention of modern science. Minneapolis: The University of Minnesota Press.

Stoller, Paul. 1989. The taste of ethnographic things. The senses in anthropology. Philadelphia: University of Pennsylvania Press.

Strathern, Marilyn. 1992. After nature. English kinship in the twentieth century. Cambridge: Cambridge University Press.

Subbaiah, Kiran. 1997. While the mouth is still full. Video Installation, Exhibition "Paris-Delhi-Bombay..." Centre Pompidou, Paris, 25 May-19 September 2011.

Sutton, David E. 2001. Remembrance of repasts. An anthropology of food and memory. Oxford: Berg.

Teil, Geneviève. 1997. "De la rosée et du miel distillés avec le parfum des fleurs sauvages : Une promenade autour de la qualité des vins.” Themed issue, "La qualité." Annales de l'École des Mines Mines. Réalités Industrielles 96: 104111.

Tsing, Anna. 2004. Friction. An ethnography of global connections. Princeton: Princeton University Press.

Verran, Helen. 2001. Science and an African logic. Chicago: University of Chicago Press.

Wiggins, Sally. 2002. "Talking with your mouth full: gustatory mmms and the embodiment of pleasure." Research on language and social interaction 35 (3): 311-336.

Wilk, Richard. 2009. "Difference on the menu: Neophilia, neophobia and globalization.” In The Globalization of food, edited by David Inglis and Debra Gimlin, 185-196. New York: Berg Publishers.

Woolgar, Steve. 2008 "Acting with mundane technologies: some examples of resistance.” Key Note, $4 \mathrm{~S}$, Rotterdam, $22^{\text {nd }}$ August. 


\section{Mélanger les méthodes, goûter des doigts: notes à propos d'une expérimentation ethnographique}

Résumé : Cet article rend compte d'une expérimentation ethnographique. Quatre experts dans l'art de manger avec les doigts et trois novices s'installèrent pour manger un plat chaud à la main. En s'appuyant sur la technique de trafiquer l'étrange et le familier, notre but n'était pas d'expliquer nos réactions mais de les articuler. En cherchant des mots pour y parvenir, nous nous voyons contraints d'étendre la portée du verbe " goûter ». Goûter, tel que notre expérimentation ethnographique le suggère, ne doit pas être résumé à une activité confinée à l'usage de la langue. Plutôt, si on lui en offre l'opportunité, elle pourrait s'étendre et couler jusqu'aux doigts, et en venir à inclure des réactions d'appréciation qui sont bien difficile à qualifier. Le plaisir et la gêne, la vitalité de la nourriture et des corps, le titillement érotique, la satisfaction ou l'inconfort qui suivent un repas - nous proposons que tous ces aspects soient regroupés dans l'action de goûter. Dès lors, jouer avec les mots change ce que peuvent dire et ressentir ceux qui parlent et ceux qui mangent, et enrichit les répertoires d'expression disponibles. Mais nous laissera-t-on faire ? Nous sera-t-il permis de mettre la pagaille dans les manuels de biologie de cette façon et de troubler, non seulement la théorie anthropologique, mais la langue anglaise elle-même ?

Anna MANN is researching tasting and the appreciation of food as a $\mathrm{PhD}$ on the ERC funded research project "Eating bodies in Western practice and theory" at the University of Amsterdam.

Annemarie MOL is Professor of Anthropology of the Body at the University of Amsterdam and directs that project.

Priya SATALKAR is trained in medicine, public health, medical anthropology and bioethics and is currently an independent researcher.

Amalinda SAVIRANI is doing research on the textile industry in Indonesia, while teaching in the faculty of social and political sciences of Gadjah Mada University, Indonesia.

Nasim SELIM studied medical anthropology in Amsterdam at the time of our experiment; earlier she studied medicine and public health and currently she is a Senior Lecturer at the James P. Grant School of Public Health, BRAC University, Bangladesh.

Malini SUR is a doctoral candidate at the Amsterdam Institute for Social Science Research and a member of the "Illegal but licit" research collective at the University of Amsterdam.

Emily YATES-DOERR holds a PhD in Anthropology from New York University and currently participates in the ERC funded research project "Eating bodies in Western practice and theory" at the University of Amsterdam. 